Original Article

\title{
The perioperative changes in physical function and physique of patients with gastrointestinal cancer
}

\author{
TSUYOSHI HARA ${ }^{1)^{*}}$, AKIRA KuBO ${ }^{2)}$ \\ 1) Department of Rehabilitation, International University of Health and Welfare Mita Hospital: 1-4-3 \\ Mita, Minato-ku, Tokyo 108-8329, Japan \\ 2) Department of Physical Therapy, Faculty of Health Science, International University of Health and \\ Welfare, Japan
}

\begin{abstract}
Purpose] The purpose of this study was to observe the long-term change in physical function and physique from perioperative to discharge of patients with gastrointestinal cancer. [Subjects and Methods] Subjects were 47 perioperative patients with gastrointestinal cancer [ 25 men and 22 women aged $61.3 \pm 11.0$ years (mean $\pm \mathrm{SD}$ )] Six-minute walk distance was measured for physical function and body mass index and calf circumference were measured for physique. These items were evaluated at three time points: before surgery, after surgery, and after discharge. [Results] Significant declines in physical function and physique were observed temporarily after surgery. Physical function improved equally before surgery in after discharge. On the other hand, postoperative physique was significantly lower than that observed pre-operatively. [Conclusion] These results suggest that the perioperative changes in physical function and physique follow different courses in patients with gastrointestinal cancer.

Key words: Gastrointestinal cancer, Physical function, Physique
\end{abstract}

(This article was submitted Aug. 21, 2014, and was accepted Oct. 15, 2014)

\section{INTRODUCTION}

Globally, the number of cancer survivors is increasing due to advances in treatment technology and early diagnosis ${ }^{2)}$. In recent years, outcomes of cancer patients have become important not only from the aspects of survival rate and life expectancy, but also from the perspective of their Quality of Life (QOL), i.e. their living conditions after discharge and satisfaction with medical care $^{1)}$.

The importance of exercise intervention has been pointed out in the improvement of the QOL of cancer patients ${ }^{3-8)}$ and other patients $^{9-11)}$ all over the world. Exercise intervention significantly improves physical function, mental function, fatigue, and QOL of cancer patients ${ }^{3-8)}$. However, the cancer patients in these cited studies received adjuvant therapy for more than one year after surgery, and to date, there has been no study of perioperative cancer patients. In addition, skeletal muscle mass has been reported to be factor affecting the course after surgery of perioperative cancer patients ${ }^{12-17)}$. However, skeletal muscle mass and physical function do not exhibit a linear relationship ${ }^{18,19)}$.

Therefore, the purpose of this study was to observe the long-term changes in physical function and physique from

*Corresponding author. Tsuyoshi Hara (E-mail: tsuyoshi-h@, iuhw.ac.jp)

(C2015 The Society of Physical Therapy Science. Published by IPEC Inc. This is an open-access article distributed under the terms of the Creative Commons Attribution Non-Commercial No Derivatives (by-ncnd) License $<$ http://creativecommons.org/licenses/by-nc-nd/3.0/> . perioperative to discharge of patients with gastrointestinal cancer who account for about $45 \%$ of cancer sufferers in $\mathrm{Japan}^{20)}$. In addition, no previous studies have tracked the physical function and physique of perioperative patients with gastrointestinal cancer.

\section{SUBJECTS AND METHODS}

The subjects were 63 perioperative patients with gastrointestinal cancer [ 38 men and 25 women aged $62.0 \pm$ 10.4 years (mean \pm SD)] (Table 1$)$. An explanation of the purpose of this study was given to the subjects, who then voluntarily gave their consent to participation. Inclusion criteria were a Functional Independence Measure perfect score before surgery, and return to home after discharge. Exclusion criteria were development of postoperative complications, long-term administration of total parenteral nutrition and bone metastasis. Sixteen three subjects were eliminated by the exclusion criteria, leaving a total of 47 patients who completed the study. This study was approved by the ethics committee of the International University of Health and Welfare Mita Hospital (H23-05). In addition, all subjects in this study only received aggressive rehabilitation intervention during hospitalization.

The study design was a prospective observational study. We measured the subjects' physical function and physique. These items were evaluated at three time points: more than one day before surgery (before surgery), 10 days after surgery (after surgery), and after return to home in the period 28 days after surgery (after discharge).

Physical function was measured by as the 6-minute 
Table 1. Characteristics of the perioperative patients with gastrointestinal cancer in the study

\begin{tabular}{|c|c|c|c|c|}
\hline & & All patients & Control group & Exclusion group \\
\hline & & $(\mathrm{n}=63)$ & $(n=47)$ & $(n=16)$ \\
\hline Age (years) & & $62.0 \pm 10.4$ & $61.3 \pm 11.0$ & $64.3 \pm 8.2$ \\
\hline \multirow[t]{2}{*}{ Gender (n/\%) } & men & $38 / 60$ & $25 / 53$ & $13 / 81$ \\
\hline & women & $25 / 40$ & $22 / 47$ & $3 / 19$ \\
\hline \multirow[t]{4}{*}{ Cancer stage (n/\%) } & I & $24 / 38$ & $17 / 36$ & $7 / 44$ \\
\hline & II & $12 / 19$ & $8 / 17$ & $4 / 25$ \\
\hline & III & $11 / 17$ & $8 / 17$ & $3 / 19$ \\
\hline & IV & $16 / 25$ & $14 / 30$ & $2 / 13$ \\
\hline \multirow[t]{6}{*}{ Surgical site (n/\%) } & Esophagus & $1 / 2$ & $0 / 0$ & $1 / 6$ \\
\hline & Stomach & $17 / 27$ & $13 / 28$ & $4 / 25$ \\
\hline & Liver & $11 / 17$ & $9 / 19$ & $2 / 13$ \\
\hline & Pancreas & $1 / 2$ & $0 / 0$ & $1 / 6$ \\
\hline & Colon & $24 / 38$ & $18 / 38$ & $6 / 38$ \\
\hline & Rectum & $9 / 14$ & $7 / 15$ & $2 / 13$ \\
\hline \multirow[t]{2}{*}{ Surgical procedure (n/\%) } & Laparoscopic & $34 / 54$ & $27 / 57$ & $7 / 44$ \\
\hline & Laparotomy & $29 / 46$ & $20 / 43$ & $9 / 56$ \\
\hline Opration time (minute) & & $288.9 \pm 130.9$ & $268.0 \pm 88.7$ & $350.4 \pm 203.3$ \\
\hline Blood loss (ml) & & $450.0 \pm 911.3$ & $346.7 \pm 685.3$ & $753.5 \pm 1364.1$ \\
\hline \multirow[t]{3}{*}{ C-reactive protein } & Before surgery & $0.25 \pm 0.39$ & $0.23 \pm 0.41$ & $0.31 \pm 0.33$ \\
\hline & After surgery & $2.13 \pm 2.40$ & $1.85 \pm 2.07$ & $2.94 \pm 3.10$ \\
\hline & After discharge & - & $0.73 \pm 2.18$ & - \\
\hline \multirow[t]{5}{*}{ Comorbidity } & Hypertension & $11 / 17$ & $8 / 17$ & $3 / 19$ \\
\hline & Dyslipidemia & $4 / 6$ & $3 / 6$ & $1 / 6$ \\
\hline & Diabetes Mellitus & $5 / 8$ & $2 / 4$ & $3 / 19$ \\
\hline & Heart Disease & $3 / 5$ & $2 / 4$ & $1 / 6$ \\
\hline & Lung Disease & $1 / 2$ & $1 / 2$ & $0 / 0$ \\
\hline Length of stay (day) & & $18.2 \pm 11.1$ & $15.8 \pm 4.6$ & $25.1 \pm 19.4$ \\
\hline \multirow[t]{3}{*}{ Day of evaluation (POD) } & Before surgery & $-1.6 \pm 0.8$ & $-1.7 \pm 0.9$ & $-1.6 \pm 0.8$ \\
\hline & After surgery & - & $9.8 \pm 1.5$ & - \\
\hline & After discharge & - & $27.9 \pm 5.2$ & - \\
\hline
\end{tabular}

The values of age, surgical procedure, operation time, blood loss, C-reactive protein, length of stay and day of evaluation are shown as mean $\pm \mathrm{SD}$. Other items are presented as percentages or numbers of cases. POD: postoperative day

walk distance (6MWD). 6MWD was performed based on the guideline of the American Thoracic Society ${ }^{21)}$. Subjects were asked to walk at maximum speed for 6 minutes on a circular track, and the distance they walked was measured by the examiner.

Physique was measured as body mass index (BMI), and calf circumference (CC), which is associated with skeletal muscle mass ${ }^{22)}$. BMI was calculated using subjects' height and weight while wearing clothes using the equation: BMI = weight $(\mathrm{kg}) /$ height $^{2}\left(\mathrm{~m}^{2}\right)$. CC was measured with a tape measure at the point of maximum bulge, and was recorded as the sum of the left and right measurements.

All data were analyzed using IBM SPSS Statistics 21.0 for Windows. One factor repeated measures analysis of variance and a multiple comparison test (Bonferroni) were used to compare 6MWD, BMI and $\mathrm{CC}$ among the three evaluation times. $\mathrm{P}$ values of less than 0.05 were considered to be significant.

\section{RESULTS}

The changes of each parameter are shown in Table 2. A significant main effect was found for independent variable (factor of three evaluation times) for all the parameters. In the multiple comparison test, 6MWD showed significant differences between before and after surgery, and after surgery and after discharge. In addition, BMI and CC showed significant differences between before and after surgery, after surgery and after discharge, and before surgery and after discharge.

\section{DISCUSSION}

In the living body, invasive surgery triggers protein catabolism through amino acid release from skeletal muscle of the whole body and activation of the immune response, in order to prevent the invasion of pathogens, and to repair damaged cells ${ }^{23)}$. Protein catabolism after surgery has been reported to 
Table 2. Long-term changes of each parameter in perioperative patients with gastrointestinal cancer

\begin{tabular}{lccc}
\hline & \multicolumn{3}{c}{ Evaluation times } \\
\hline & Before & After & After \\
& surgery & surgery & discharge \\
\hline 6MWD $(\mathrm{m})^{*},{ }^{* * a}$ ab) & $480.7 \pm 90.8$ & $445.8 \pm 100.4$ & $480.2 \pm 102.4$ \\
BMI $\left.\left(\mathrm{kg} / \mathrm{m}^{2}\right)^{*},{ }^{* *} \mathrm{a}-\mathrm{c}\right)$ & $21.7 \pm 2.7$ & $20.7 \pm 2.7$ & $21.0 \pm 2.8$ \\
$\left.\mathrm{CC}(\mathrm{cm})^{*}{ }^{* * a-c}\right)$ & $68.7 \pm 6.6$ & $65.7 \pm 6.6$ & $67.9 \pm 6.5$ \\
\hline
\end{tabular}

The values of each parameter are shown as the mean \pm SD. 6MWD: 6-minute walk distance; BMI: body mass index; CC: calf circumference. ${ }^{*}$ one-factor repeated measures analysis of variance, ${ }^{* *}$ multiple comparison test (Bonferroni), a) before surgery vs. after surgery, b) after surgery vs. after discharge, c) before surgery vs. after discharge.

be greatest on the first day after surgery. Protein catabolism is higher than anabolism in the first 10 days after surgery in perioperative patients with gastrointestinal cancer ${ }^{24)}$. In the patients with gastrointestinal cancer, this is the environment in which muscle atrophy and loss of physical function is likely to occur. We observed a significant decline of physical function and physique of the perioperative patients with gastrointestinal cancer in this study, and we consider protein catabolism after surgery is a factor affecting this as has been suggested by previous studies. Physical function and physique significantly improved between after surgery and after discharge. We speculate that the reasons behind this are that protein metabolism stabilizes after 10 days after surgery, and that physical activity increases on return to home when it is in the anabolic phase ${ }^{24)}$.

Physique was significantly reduced, compared with before surgery, after discharge. A previous study reported that muscle hypertrophy recovery was slower than muscle function in healthy subjects who received retraining after a certain period of immobilization ${ }^{25}$. Accordingly, the observed post-surgery calf muscle slimming suggests the possibility of a delay in recovery from muscle atrophy due to a reduction in mechanical stimulation associated with the activity loss in the time of acute rest before return to home in the patients with gastrointestinal cancer.

A limitation of this study was that we did not consider other factors influencing physical changes in the perioperative period such as intake of protein and water after surgery, surgery site, surgical stress, cancer stage, comorbidity or physical activity after surgery. A future study will be necessary to re-examine the relationship between physique and these influencing factors in perioperative patients with gastrointestinal cancer.

\section{REFERENCES}

1) Main DS, Nowels CT, Cavender TA, et al.: A qualitative study of work and work return in cancer survivors. Psychooncology, 2005, 14: 992-1004. [Medline] [CrossRef]

2) de Boer AG, Taskila T, Ojajärvi A, et al.: Cancer survivors and unemployment: a meta-analysis and meta-regression. JAMA, 2009, 301: 753-762. [Medline] [CrossRef]
3) Courneya KS, Segal RJ, Mackey JR, et al.: Effects of aerobic and resistance exercise in breast cancer patients receiving adjuvant chemotherapy: a multicenter randomized controlled trial. J Clin Oncol, 2007, 25: 43964404. [Medline] [CrossRef]

4) Fong DY, Ho JW, Hui BP, et al.: Physical activity for cancer survivors: meta-analysis of randomised controlled trials. BMJ, 2012, 344: e70. [Medline] [CrossRef]

5) McNeely ML, Campbell KL, Rowe BH, et al.: Effects of exercise on breast cancer patients and survivors: a systematic review and meta-analysis. CMAJ, 2006, 175: 34-41. [Medline] [CrossRef]

6) Mutrie N, Campbell AM, Whyte F, et al.: Benefits of supervised group exercise programme for women being treated for early stage breast cancer: pragmatic randomised controlled trial. BMJ, 2007, 334: 517. [Medline] [CrossRef]

7) Segal RJ, Reid RD, Courneya KS, et al.: Randomized controlled trial of resistance or aerobic exercise in men receiving radiation therapy for prostate cancer. J Clin Oncol, 2009, 27: 344-351. [Medline] [CrossRef]

8) Thorsen L, Courneya KS, Stevinson C, et al.: A systematic review of physical activity in prostate cancer survivors: outcomes, prevalence, and determinants. Support Care Cancer, 2008, 16: 987-997. [Medline] [CrossRef]

9) Ota M, Kaneoka K, Hangai M, et al.: Effectiveness of lumbar stabilization exercises for reducing chronic low back pain and improving quality-oflife. J Phys Ther Sci, 2011, 23: 679-681. [CrossRef]

10) Takemasa $S$, Nakagoshi R, Murakami M, et al.: Factors affecting quality of life of the homebound elderly hemiparetic stroke patients. J Phys Ther Sci, 2014, 26: 301-303. [Medline] [CrossRef]

11) Kim K, Kim YM, Kim EK: Correlation between the activities of daily living of stroke patients in a community setting and their quality of life. $\mathrm{J}$ Phys Ther Sci, 2014, 26: 417-419. [Medline] [CrossRef]

12) Peng PD, van Vledder MG, Tsai $S$, et al.: Sarcopenia negatively impacts short-term outcomes in patients undergoing hepatic resection for colorectal liver metastasis. HPB Oxf, 2011, 13: 439-446. [Medline] [CrossRef]

13) van Vledder MG, Levolger $\mathrm{S}$, Ayez N, et al.: Body composition and outcome in patients undergoing resection of colorectal liver metastases. Br J Surg, 2012, 99: 550-557. [Medline] [CrossRef]

14) Peng P, Hyder O, Firoozmand A, et al.: Impact of sarcopenia on outcomes following resection of pancreatic adenocarcinoma. J Gastrointest Surg, 2012, 16: 1478-1486. [Medline] [CrossRef]

15) Lieffers JR, Bathe OF, Fassbender K, et al.: Sarcopenia is associated with postoperative infection and delayed recovery from colorectal cancer resection surgery. Br J Cancer, 2012, 107: 931-936. [Medline] [CrossRef]

16) Harimoto N, Shirabe K, Yamashita YI, et al.: Sarcopenia as a predictor of prognosis in patients following hepatectomy for hepatocellular carcinoma. Br J Surg, 2013, 100: 1523-1530. [Medline] [CrossRef]

17) Reisinger KW, van Vugt JL, Tegels JJ, et al.: Functional compromise reflected by sarcopenia, frailty, and nutritional depletion predicts adverse postoperative outcome after colorectal cancer surgery. Ann Surg, 2014, Epub ahead of print. [Medline] [CrossRef]

18) Janssen I, Baumgartner RN, Ross R, et al.: Skeletal muscle cutpoints associated with elevated physical disability risk in older men and women. Am J Epidemiol, 2004, 159: 413-421. [Medline] [CrossRef]

19) Goodpaster BH, Park SW, Harris TB, et al.: The loss of skeletal muscle strength, mass, and quality in older adults: the health, aging and body composition study. J Gerontol A Biol Sci Med Sci, 2006, 61: 1059-1064. [Medline] [CrossRef]

20) Matsuda T, Marugame T, Kamo K, et al. Japan Cancer Surveillance Research Group: Cancer incidence and incidence rates in Japan in 2005: based on data from 12 population-based cancer registries in the Monitoring of Cancer Incidence in Japan (MCIJ) project. Jpn J Clin Oncol, 2011, 41: 139-147. [Medline] [CrossRef]

21) ATS Committee on Proficiency Standards for Clinical Pulmonary Function Laboratories: ATS statement: guidelines for the six-minute walk test. Am J Respir Crit Care Med, 2002, 166: 111-117. [Medline] [CrossRef]

22) Rolland Y, Lauwers-Cances V, Cournot M, et al.: Sarcopenia, calf circumference, and physical function of elderly women: a cross-sectional study. J Am Geriatr Soc, 2003, 51: 1120-1124. [Medline] [CrossRef]

23) Lin E, Calvano SE, Lowry SF: Systemic Response to Injury and Metabolic Support. New York: McGraw-Hill, 2005, pp 3-41.

24) Souba WW, Austgen TR: Interorgan glutamine flow following surgery and infection. JPEN J Parenter Enteral Nutr, 1990, 14: 90S-93S. [Medline] [CrossRef]

25) Suetta C, Hvid LG, Justesen L, et al.: Effects of aging on human skeletal muscle after immobilization and retraining. J Appl Physiol 1985, 2009, 107: 1172-1180. [Medline] [CrossRef] 